illumination. can be seen to have al well-refined and somewhat thickened. irregular border. Slight hazy opalcities can be seen in tlee center of the disk, and the same to a less dearee ontside of same in the posterior cortical plane of the lens.

That this case is exactly similat in type to glassblower's catalaret is proved hy the worts of Herbert Par-

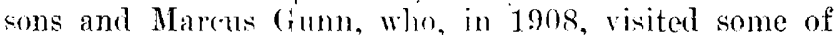
the important glass-works in Englanel for the Roval Society, to gather statistics of industrial chiseases for the framing of the Workmen's Compensation Act. They say :

Bottle-makers are subject to a form of cataract which appears to be characterintic. and is unlike other forms of cataract commonly observed. In its typical form there is a dense. well-defined disk of opacity in the center of the posterior cortex. Not infrequently slighter hazy opacities are seen around this mosterior cortical disk.

Hirschberg describes it in a similar way, and in 1898 cxhibited five ases of glass-blower's ataract. At the same time he drew attention to the peculiar color of the faces-the effect of heat on the skin. Most of the German literature on the subject secms to conrerle that heat is the factor that produces these changes in the lens and skin.

Hevl* mentions fire-workers, blacksmitls, puddlers, bakers and cooks as subject to this same change in the lens.

In a volume on industrial diseases, 1909, Greer sars of bottle-maker's cataract: "It rommences as a saucershaped opacity like a cobwely in appearance, and situated immediately within the posterior amsule of the lens."

The treatment which I am using is the method of von Pflugk and Verderau-instillations of 2 per cent. solution of potassium indid, to be followed later by subconjunctival injertions of the same. According to Hirschberg. these conses progress rery slowly until $20 / 200$ vision has been reached, when often a more rapid deoline follows. When ready for operation ther present a most favolable trpe for sucessiful extraction.

3f Washington Street.

\section{THE DIAGNOSTIC VALUE OF THE PARADOXIC REFLEX}

AN ADDITIOAAL ANATOMIC PROOF OF ITS PRICTICAL IMIPORTA ITCE

\section{ALFRED GORDON. M.D. PHILADELIIIA}

In December, 190)/, I described a new reflex umler the name of paraloxie flexor reflex. I found it then prosent in eases the history of which pointer to organic diseases of the nerrous sistem and especially of its motor tracts, and alwars associated with exaggerated knee-jerks. As is well known, Babinski's toe phenomenon is the clinical expression of a disease of the motor patliwar.

The reflex an be elicited in the following manner: The pationt may either lie on his hack or sit on a chair with the feet (not the legs) on a stool. 'The feet must be slightly rotated externally; in this position complete relaxation of the muscles of the leg is obtained. The examiner must always place himself at the outer side of the leg; the thenar and hypothenar muscles of the right hand must be placed on the inner surface of the

* Ireyl: Handbuch der Arbeiterkrankhciten, 1918.

* Weyl : Ilandbuch der Arbciter
1. Am. Mor., 1904, viii, 971. tibia of the patient and the fingers press deeply on the midlle or the lower portion of the calf muscles. I say "dueply" because the pressure must be transmitted to the flexor mus:les of the deep layer; sometimes pressure must be combined with lateral moirements of the superficial muscles. If the refiex is present, extension of the great toe, or of all the toes, will he noticed. There is evidently no other muscle except the flexors that conld be brought into displar. The tibialis posticus, the peronei have an entirely different function from flexion or extension of the toes.

J) ring my investigations I observed a peculiar relationship between these two reflexes. Babinski's sign was sometimes present and sometimes absent, but in the majority of my ases the paradoxic reflex was present on the side on which the Babinski sign was either absent or slight. It was present in those obscure cases in which the Babinski reflex was not obtainable.

My first series comprised thirty organic cases, in nineteen of which I observed that Babinski's sign and the paradoxic reflex showed a tendeney to replace each other; riz., when one was slight, the other was marked and rice repst. There was a species of antagonism between the two reflexes.

My observations at the time of the first report were purely clinical. I lad no anatomic proof to offer.

In "December, 1908, I made a second report to the Plibadelphia Nevirological Society on fifty-eight cases. The diseases in which the reflex was studied were as follows: transverse myelitis, anvotrophic lateral selorosis, hemiplegia, Jacksonian epilepst, disseminated sclerosis, cerebrospinal syphilis and essential cpilepsy. Here again I observed the same antagonism between the Babinski and paradoxic reflexes, viz., when one was present and pronounced. the other was absent; when one was mild, the otlier was pronouncerl. The latter fact was particularly conspicuous in seven cases of transverse myelitis: at first Babinski's sign was absent on one or both sides and the pardoxic reflex was present; two or three months later Balinski's sign made its appearance, and the pardoxic reflex completely disappeared or was faintly present. In one case of cerebrospinal syphilis in which the spinal symptoms were the most conspicuous, energetic mercurial treatment was instituted. The patient's mental functions, the ataxia and sphincters improved considerably. The knec-jerks, however, remained markelly exaggerated; ankle-clonus wa present on one side, but Babinski's sign disappeared on one side and was only slightly preserved on the other; the paradoxic reflex remained intact and was easily obtainable.

As another illustration of the antagonistic relationship of the two reflexes may be mentioned six cases of Jacksonian epilepsy of the sime scries. In all there was paresis on the same side. When the examination was marle immediately or shortly after the attacks, the kneejerk was exaggerated on the affected side and the paradoxic reflex was easily alicited in all the cases, while Babinski's sign was in three cases only slightly present and in two others absent.

An analysis of all the facts observed and followed up led me to the conclusion that the paradoxic reflex is a raluable sign for diagnostic purposes at the beginning of an organic aftection showing that the motor tract is being irritated: while Babinski's sign is of inestimable value in cases of a well-established lesion of the motor tract, the paradoxic reflex is a sign, to say the least, of a transient irritation or of a slight lesion of the same tract. 
That a transient irritation may be the cause of the reflex can be seen among other facts, especially from the following rase:

('Ast 1.-A lad of 12 , in the course of typhoid fever, developed meningeal symptoms. He then had an attack of epileptiform convulsions on the right side which were followed by paralytic symptoms on the same side. I had an opportunity to examine him twice at an interval of two weeks. On both cerasions the right knee-jerk was markedly exaggerated, there was no ankle-clonus and no Babinski sign, but the paradoxic reflex was present and easily elicited. The patient made a complete recovery; the paralytic symptoms, the increased knee. jerk and the paradoxic reflex disappeared.

My syctematic study of sixty ases of paretic dementia" with reference to the reflexes of the lower extremities demonstrate the great rarity of the Bahinski sign (on both sides in three cases and on one sicle in four cases), but the great frequency of the paradoxic refiex (in fortytwo cases) in this disease. According to the pathologic reports in cases of paresis, the motor pathway is involved only to a very slight rlegree in the majority of instances. As Babinsli's sign is usually the clinical expression of a woll-defined legenerative lesion of the motor tract, the very moderate degree of prramidal involvement will perhaps explain satisfactorily the rarity of Babinski's phenomenon in paresis. On the other hand, the presence of the paradoxic reflex in the largest number of my paretic cases fincls its logical explanation in the slight degree of pyramidal inrolvement. This olservation in paresis is therefore analogous to, if not identical with, the observation made in other organic nervous diseases, and tends to show, I believe, the correctness of my confention makle in my arliest study of the significaner of the paradoxic reflex.

From the sinical stantpoint the diagmostic value of the paradoxic reflex appeared therefore to be established; it remained for me to corroborate it by anatomic proofs. That is to say, it was necessary to show that a reil anatomic lesion was present in those ases in which during life the paradoxic reflex was the only or the most conspicuous sign and in which operative procedures were undertaken for this reason with satisfactory results so far as the finding of the lesion is concerned. Soon such opportunities prosenter themselves.

In 1906 and 1907 , I hat the opportmity to observe two cases.3

(ase 2.-In this case, in which a localized hemorrhagic pachymeningitis was found in the right motor area, the para doxic reflex was very distinct on the left together with a slightly exaggerated knee-jerk on the same side, but there wats total alsence of Babinski's and Oppenheim's toe phenomena and of ankle-clomus. The paradoxie sign was the mont promi nent symptom. When the blond was removed by the surgeon from the right hemisphere, the patient regained consciousnes (he was deeply comatose before the operation), improved considerably and on the second day the patellar tendon reflex herame normal and the paradoxic sign totally disappeared. Four days lates, the same phenomena returned and the patient again beame stuporous; the abnormal reflexes returned. The patient died two days later. Autopsy showed a reformation of the blood clot in the right hemisphere over the Rolandic area.

( Ase 3. -This concerns a man who complained of pain in the right side of the head in the same place where he received an injury six montls previously. There was also marked mental hebetude and sommolence. The left knee-jerk was exaggerated anl the paradoxic reflex was obtained with the greatest facility. There wals no Baljinski reflex, no Oppenleim sign, no ankleclomus. The contrast hetween the flexion of the toes on the

2. Jour. Norv and Mental Dis, July, 1907.
3. Rev. Neurol., No. 22, 1906 ; and Am. Jour. Med. Sei., August, 11107 right side and extension on the left on prossure of the calf muscles was most striking. Trephining of the skull with exposure of the inper part of the Rolandic area was performed. As the opening was mate, the cerebral tissue bulged out; it was evidently under bigh tension. The surgeon immerliately closed it up. Rapidly the patient regained lis intelligener'; the somnolence and healache totally disappeared. At the end of forty-eight hours the paraloxic reflex became woaker surl on the fourth day could no more be elicited. The patient was reexamined six weeks later; the paradoxic reflex and the increase of the knee-jerk were totally absent.

These two ases with the anatomic prools corrolorated in the most forceful manner the conclusions which I reached at the beginning of my stulies from purely clinical observations, to wit, that the paradoxic reflex is a sign of value in the beginning of an organic affection of the motor system or in cases of its irritation, while Balsinski's sign is of inestimable value in cases with a definitely established lesion of the motor pathway.

I wisli to ald a third anatomo-clinical case which, like the previous two, presents an exceedingly definite jllustration of the diagnostic value of the paradoxical reflex and of its practical bearing.

('AsE 4.-History.-An Jtalian laborer, agerl 23, of excellent health, during a quarrel sustained an injury over the left fyontoparietal region at its upjer level. He was struck with a piece of heavy iron. Laceration of the scalp ensued and a swelling of the parts of the size of a silver half collar followed. There was no loss of consciousness, but mental hehetude and distinct motor aplosia developed. All the man could sily was "yes" or "no." "The patient came under my observation through the courtesy of Dr. I. Cortese about ten days after the trauma. On examination I found the above-mentioned helotude and the motor aphasia. l'he patient could comprehend fairly well when spoken to, but was unable to articulate. Various objects were shown him and wrong names given them; when asked whether they were the projer names of the objects, he answered correctly "yes" or "no." Voluntarily, he (omld not articulate otlier words, or repeat them when spoken to lim. There was no word-blimbluesis or word-deafuess.

Examination.-Physical examination showed good station and gait. The power of the right lower extremity was very slinhtly diminished, so slightly that the defect could be easily overlooked if the patient were not very closely examined. 'Jlis was done by testing the resisting power of the thigh, leg and foot and comparing it with that of the corresponding segments on the opposite side. The right kneo-jerk was also slightly more marked than the left; nevertheless the difference was distinct on repeated examinations. There was no ankle-clonus, no 3rabinski reflex, no Oppenheim sign. 'The paradoxic reflex was present on the right side in the most conspicuous manner; it could be elicited, with the greatest facility, during the entire fifteen days before the operation. The scalp presented the above-mentioned elevation over a small area at the uppermost portion of the left fronto-parietal region. 'The thirkness of the lacerated surface prevented an exact determination of the romblition of the malerlying bony tissue; pressure provoked pain. however.

Treatment.-After the patient was placed in the Northwest('n General Hospital his mental conrlition began to improve and the aphasia cradually disappeared. Both the paradoxic reflex and the slightly increased knee-jerk persisted with the greatest olstinacy and at no time could either Babinski or Oppenheim sign he elicited. The condition, in my opinion, therefore, imclicated an involvement of the left motor area, probably only an irritation, but not a distinct lesion, in view of the absence of Babinski's sign. I advised an operation over the injured region of the scalp. Before operating an $x$-ray picture was taken, and a distinct involvement of the bony tissue was detected on the skiagraph. Dr. J. Thompson Schell performed an osteoplastic operation. The upper half of the Rolandie area, including the lacerated region, was exposed. A small fyament of the inner table of the skull was foumd imbedded in the dura, producing a subdural hemorrhage lying over the 
uppermost portion of the left motor area. The outer surface of the skull was intact. 'The opening of the lacerated dura was enlarged, the coagulated blood removed and the cortex exposed. 'The latter's surface was found intact; no laceration could be scen.

Result.-The pationt gradually improved and finally recovered. The mental licbetude completely disappeared. During the first two days the knec-jerk remained slightly exaggerateil, but on the fourtl day bocame normal. On the sixth day, the paraloxic reflex becaine fainter and on the twelfth day after the operation it conlil no more be elicited. It was interesting to observe its gradual diminution and disappearance and it was also interesting to notice its conspicuous presence on the morning before the operation and its gradual obliteration after the operation. The patient was subsequently secu by me several times during a perior of two months and at no time could I detect the presence of an abnormal knee-jerk or of the paradoxic reflex.

This case, I belicre, is the most striking illustration of my contention concerning the practical value of the reflex. Added to the first two cases pullished in 1906 and $190 \%, 3$ it fumishes decisive anatomic proofs for the a priori deductions made from clinical observations. The reflex has its diagnostic value and descrves a place in nosology of the nerrous system.

In conclusion, I may mention that a systematic inrestigation was made by me in 800 individuals free from diseases of the nervous srstem, also in 250 cases of functional nerrous diseases and at no time was extension of the toes elicited by the method employed bx me for the detertion of the paradoxic reflex.

1430 Pine Street.

\section{THE AUTOLYSIS OF THE CRYSTALLINE LENS}

\section{A PRELIMINARY RePORT}

\section{A. CLAPP, M.D.} BAITIMIORE:

In the study of trammatic cataract and the needling opreration, 1 was struck with the very scant description of the manner in which the lens becomes opaque and the rauses for its opacity and final absorption.

Parsons ${ }^{1}$ states that after exposurc of the lens fihers to the action of the aqueous they swoll up, become opaque, protrude through the capsular wound, and finally break up in the uslat manner, absorption being largely due to the lenkocrtes, which become swollen and filled with granules.

Schlösser ${ }^{2}(188 \%)$ in an article on traumatie cataract, and Schirme:" (1889) have studied the microscopic changes rery thomolngly, but without throwing much light on the cause of these changes.

Fuchs states that the fibers swell up and becone opaque through absorption of water ; some are broken off and drop into the anterior chamber and are absorbed. But he also says that concussion without rupture of the (apsule may canse the derclopment of complete opacity of the lens. IHe, howerer, fails to state just why this oceurs.

De Schweinits says that the opacity and liquefaction are explained by the action of the sodium chlorid of the aqueous on the globulin of the lens substance, as glol)ulin is normally soluble in weak sodium chlorid solution.

1. Parsons: The I'athology of the Eye, 1904.

2. Schlöser : Experimental Studies on 'Traumatic Cataract, $18 \times 7$.

3. Schirmer: Arch. f. Ophth., 1889.

4. Fuchs: 'Text-Book of Ophthalmology, 1908.

ir. De Schweinitz: Discases of the Eye, 1910.
This theory was, I think, first suggested by Marcus Gumn in 1899 in the Ophthalmic Review.

In further search of the literature on the subject I lave found no elaboration.

In order to understand the subject it is necessary to have a knowledge of the chemistry of both the aqueous ant the crystalline lens.

Halliburton gives the composition of calves' aqueous as in 'Table 1.

\section{TABIE 1.-COMIOSITION OF THE AQUEOUS}

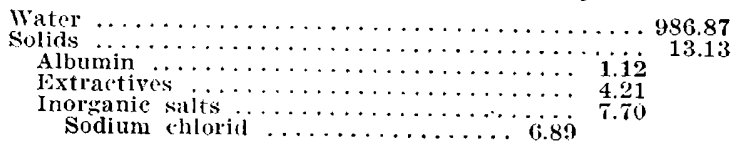

'Thus it will be seen that it consists practically of normal saline solution with a trace of albumin and cxtractives.

The composition of the lens as given by Neumeister is set forth in Table 2 .

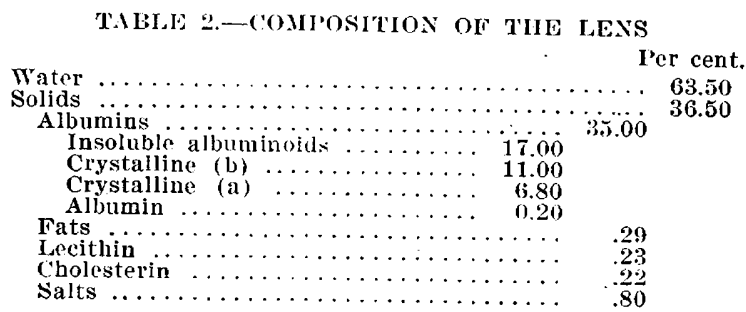

It will be scen that the lens contains 3.) per cent. of protein, the highest protein percentage of any tissue of the body. Of this 35 per cent. protein, 17 per cent. is in the form of an insoluble albuminoid which is insoluble in normal saline or water.

It is a true albumin and constitutes most of the lens fibers, its amount increasing from without inward in accorlance with the increasing age of the lens fibers. The remaining protein consists of a small amount of serum albumin and two vitellins which are soluble in dilute saline or in water.

If these analyses are correct, we have great difficulties in explaining the foregoing theories.

I can hardly agree with Parsons' statement that most of these fibers are carried off by the leukocytes. In the first place, if there is no infection there should not be many polymorphonuclear leukocytes about, as they occur chiefly in inflammatory troubles; and secondly, it would not explain the traumatic cataract with absorption in those cases of concussion without rupture of the capsule.

Fuchs seems to keep on the safe side by simply stating that the fibers become opaque and are finally absorbed, and by giving no explanation for the cause of the concussion cataract.

De Schweinitz's promulgation of Marcus Gunn's suggestion is, if the chemistry be correct, entirely untenable. To be sure the (a) and (b) crystalline bodies would be dissolved out either by water or the aqueous, but the insoluble albuminoid which makes up the greater portion of the protein, and which occurs chiefly in the lens fibers, is insoluble in either the water or the saline.

It is easily seen from a study of the chemistry of the lens why it becomes opaque either after injury with the entrance of aqueous or even from concussion. In case of rupture of the capsule and entrance of the aqueous there would occur an immediate precipitation of this insoluble albuminoid, while the remaining portions 